\title{
Electricity, Computers, Innovation, Environment and Capacity Building: A Statistical Review
}

\author{
Grace Korter ${ }^{1}$, Olusanya Olubusoye ${ }^{2}$ \\ ${ }^{1,2}$ (Department of Statistics/University of Ibadan, Nigeria)
}

\begin{abstract}
The objective was to examine the frameworks needed to foster innovations and to mobilize innovation towards co - creating computers in the context of developing countries' challenge of unreliable energy supply, in order to enhance performance of information and communication technology (ICT) as teaching aids for educational attainment. The basic underlying assumption is that computers are the simplest interactive instructional devices and that energy is a fundamental requirement for its functionality. A sample survey was conducted to ascertain the existing energy and ICT situation and needs amongst students. 213 questionnaires were administered to students of the University of Ibadan, and the Polytechnic, Ibadan in Oyo state of Nigeria. Investigation on technologies that can make the computer more relevant to users and adaptable to the environment revealed $51.4 \%$ suggesting longer battery life, $21.8 \%$ - double battery pack, $8.5 \%$ - both longer battery life and double battery pack and $7 \%$ - a reduction in the energy consumption of component parts of the computer. Apparently, there is a need to maximize the full potentials of the computer to enhance educational development and to expose students across the globe to equal platforms and opportunities for learning.
\end{abstract}

Keywords: Capacity building, Computer, Innovation, Statistics.

\section{Introduction}

Developing countries are often characterized by unreliable energy supply, poor infrastructure, no water, bad transport or limited digital access. Energy is important for education because it facilitates communication, particularly through information technology and also by provision of basic needs such as lighting. Access to energy facilitates economic development by providing more efficient and healthier means to undertake household tasks. It provide means to undertake productive activities more generally, often more cheaply than by using the inefficient substitutes such as candles, lanterns and batteries.

To bring sustainable development to the greatest number of people, it is essential to develop appropriate technology to suit existing social, cultural, environmental and economic situations. That is, technical design needs to conform to specific local context in order to achieve significant development across the globe. Past studies have examined the need for innovative technology that suit developing countries. For instance, [1] mobilized technology for developing countries in respect of overall and sectoral development objectives, economic and man power resources and the local institutional and social cultural context. The need for both hardware innovation, such as low - cost alternatives to waterborne sewerage and social (software) innovation, such as training large number of supervisors to implement improved technology for labour intensive civil works was emphasized.

[2] discussed technological innovation in the form of sharing mechanisms for information technology in developing countries designed to fit with local conditions. The author used South Africa's 'Wizzy Digital Courier' which was designed specifically for the rural parts of the school system as illustration. Another example is the 'Kisan call centres ${ }^{1}$ ' in India which operates on the basis of combining telephones and computers. So also is the one-laptop-per-child program ${ }^{2}$ (OLPC) which embodies a desirable technological feature that promotes sharing within a school and exemplifies forms of innovation.

With a focus on energy, [3] examined current approaches of the foreign assistance community to an alternation solution to the energy problem of developing countries - the introduction, adaptation and diffusion of renewable energy technologies. The paper argued for the importance of local participation, and for technology adaptation to local customs, traditions and needs.

Conventional thinking holds that increased energy consumption is a prerequisite for economic and social development. This belief, together with the prospect of dwindling global petroleum supplies and the high costs of expanding energy supply generally, lead many to believe that it is not feasible to improve living standards substantially in the developing countries. However, [4] argues that by shifting to high quality energy carriers and by exploiting cost effective opportunities for more efficient energy use, it would be possible to

\footnotetext{
Further information can be found

${ }^{1}$ http://www.manage.gov.in/kisan/default.htm

${ }^{2}$ http://www.laptop.org/
} 
satisfy basic human needs and to provide considerable further improvements without significantly increasing per - capita energy use above the present level.

Thus, without focussing on improving energy supply, a sample survey was conducted to ascertain the existing energy and ICT situation and needs amongst students of higher learning in a developing country. Questionnaires were administered to 213 students of the University of Ibadan, and the Polytechnic, Ibadan, Oyo state of Nigeria. These two higher institutions of learning happen to be amongst the oldest institutions in the western part of the country. The objective is to examine the frameworks needed to foster innovations and to mobilize innovation towards co - creating computers in the context of developing countries' challenge of unreliable energy supply, in order to enhance performance of ICT as teaching aids for educational attainment. The basic underlying assumption is that computers are the simplest interactive instructional devices and that energy is a fundamental requirement for its functionality.

The hypotheses questions were set as follow. Is there is any significant impact of poor energy supply on the use of computer as teaching aid in developing countries? Is there any significant impact of poor energy supply to information and communication technology in developing countries? Does technological innovation have any significant effect on number of hours the computer can be put to use? Is usage of computer independent of energy supply?

The paper is organized as follow: introduction, significance of information communication technology to education and development, the energy challenge, computers as interactive tools for learning, technologies to make the computer more relevant, tests of significance and lastly conclusion. Our findings should enable the orientation of technological policies targeted towards manufacturing computers to suit the unreliable energy supply challenge in developing countries.

\section{The Energy Challenge}

Since the dawn of the industrial age, the ability to harness and use different forms of energy has transformed living conditions for billions of people. For most of the last 200 years, steady growth in energy consumption has been closely tied to rising levels of prosperity and economic opportunity in much of the world. Now, however, humanity finds itself confronting an enormous energy challenge. This challenge has at least two critical dimensions. On the one hand, it has become clear that current patterns of energy use are environmentally unsustainable. At the same time, access to energy continues to divide the "haves" from the "have-nots". Not surprising, the number of people without access to electricity worldwide has hardly changed in absolute terms since $1970[5,6]$.

Today, more than 1.4 billion people worldwide lack access to electricity: 585 million people in SubSaharan Africa (including over 76 million in Nigeria and some 69 million in Ethiopia) and most of the rest in developing Asia (including 400 million in India and 96 million in Bangladesh. Some 85\% of those without electricity live in rural areas. The greatest challenge is in the Sub-Saharan Africa where today, only $31 \%$ of the population has access to electricity; the lowest level in the world. If South Africa is excluded, the share declines further to 28\%. For instance, residential electricity in Sub-Saharan Africa, excluding South Africa, is roughly equivalent to consumption in New York (Fig. 1). That is, 19.5 million inhabitants of New York consume in a year, roughly the same quantity of electricity $40 \mathrm{TWh}$, as the 791 million people of Sub-Saharan Africa.

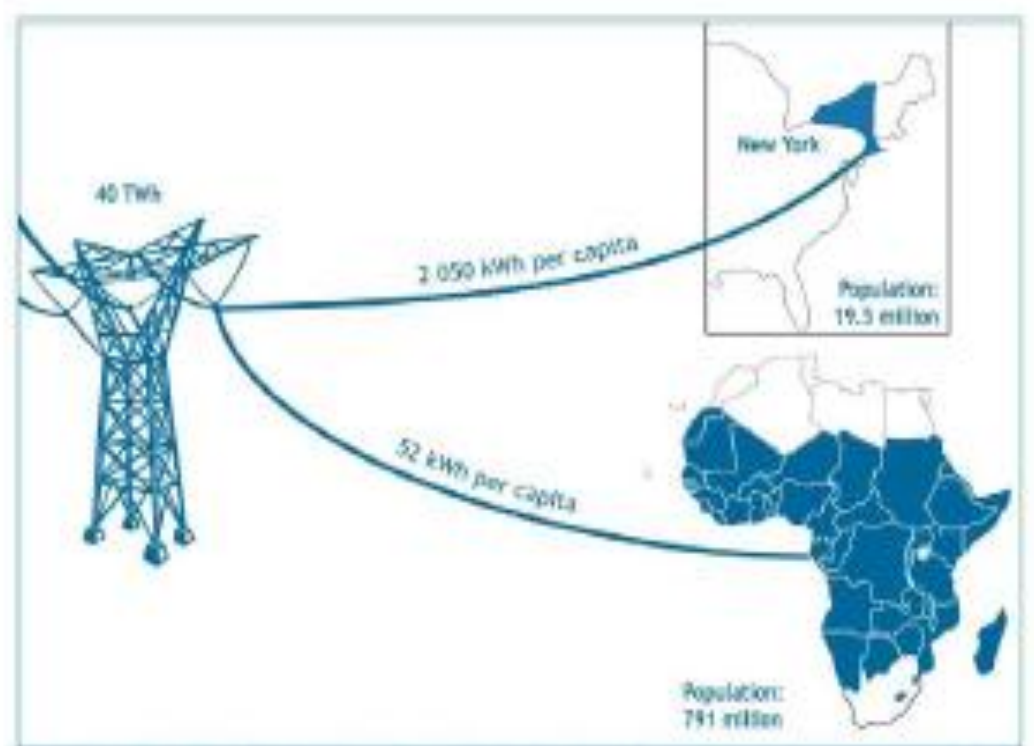

Source: International Energy Agency 2010,p.11

Figure 1: Electricity consumption in New York and Sub-Saharan Africa 
The boundaries and names shown and the designations used on maps included in this publication do not imply official endorsement or acceptance by the International Energy Agency

The International Energy Agency (IEA) has described an Energy Development Index (EDI) in order to better understand the role that energy plays in human development. It tracks progress in a country's or region's transition to the use of modern fuels. By publishing updates of the EDI on annual basis the IEA hopes to raise the international community's awareness of energy poverty issues and to assist countries to monitor their progress towards modern energy access. The EDI is calculated in such a way as to mirror the UNDP's Human Development Index and is composed of four indicators, each of which captures a specific aspect of potential energy poverty: per capita commercial energy consumption - this serves as an indicator of the overall economic development of a country; per capita electricity consumption in the residential sector - this serves as an indicator of the reliability of, and consumer's ability to pay for electricity services; share of modern fuels in total residential sector energy use - this serves as an indicator of the level of access to clean cooking facilities and lastly, share of population with access to electricity [7].

Fig. 2 ranks countries using the four energy development indicators discussed above. Except for South Africa, all Sub - Saharan African countries appear in the bottom half of the EDI. Gabon ranks second in SubSaharan Africa, behind South Africa but 23 places lower. The ranking of countries in Asia varies greatly; Myanmar amd Cambodia are in the bottom ten countries, while Malaysia is in the top ten. Pakistan has the highest EDI ranking of countries in South Asia, while Venezuela has the highest ranking of Latin American countries. Net oil - exporting countries, except for those in Sub- Saharan Africa, are all in the top third of the EDI ranking.

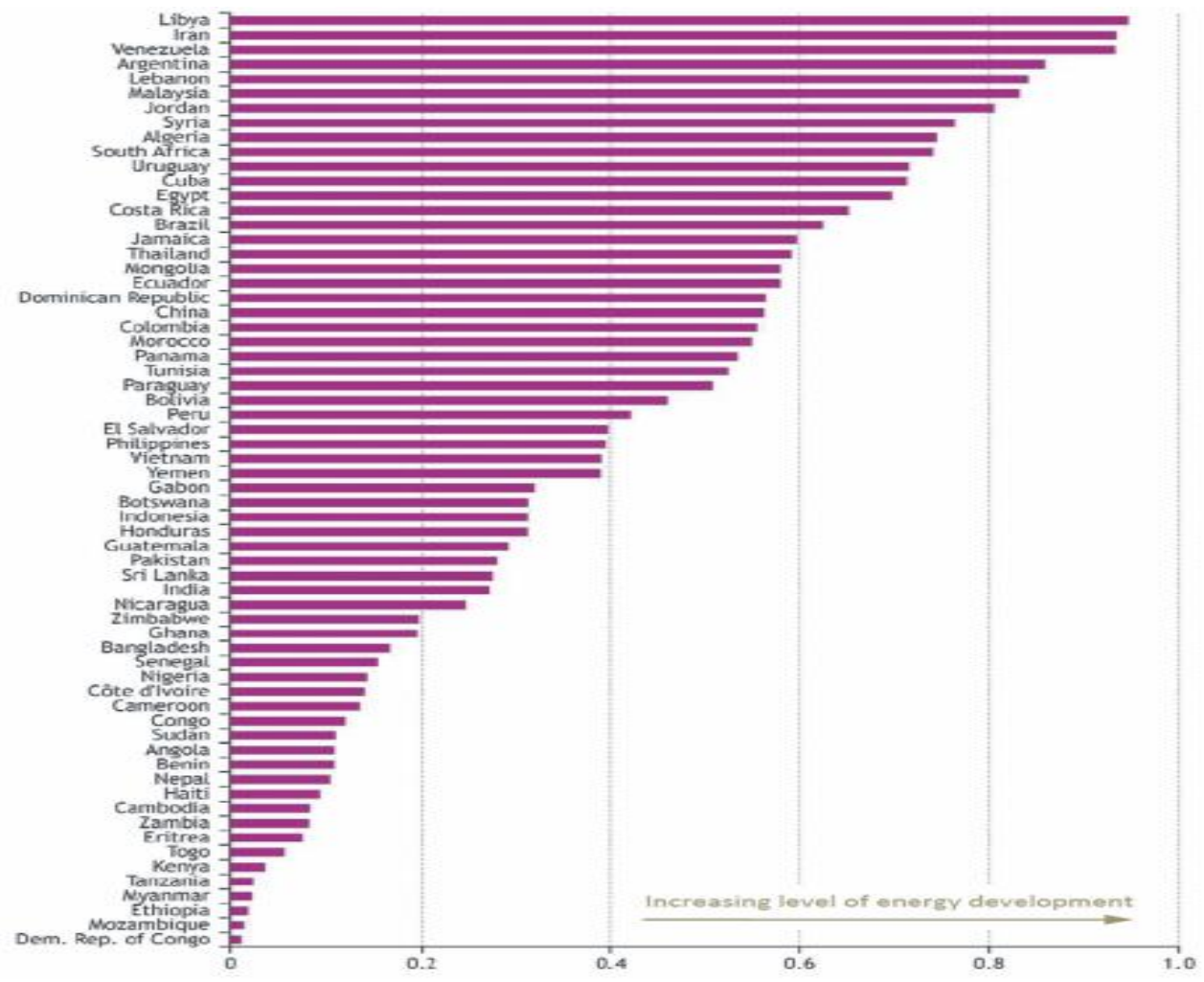

Source: International Energy Agency 2010,p.31

Figure 2: The 2010 energy development index (based on 2009 data)

Worst still, in the New Policies Scenario ${ }^{3}$, projections suggest that the problem will persist and even depeen in the longer term (Fig. 3). $87 \%$ of them living in rural areas.Most of these people will be living in SubSaharan Africa, India and other developing Asian countries excluding China. 


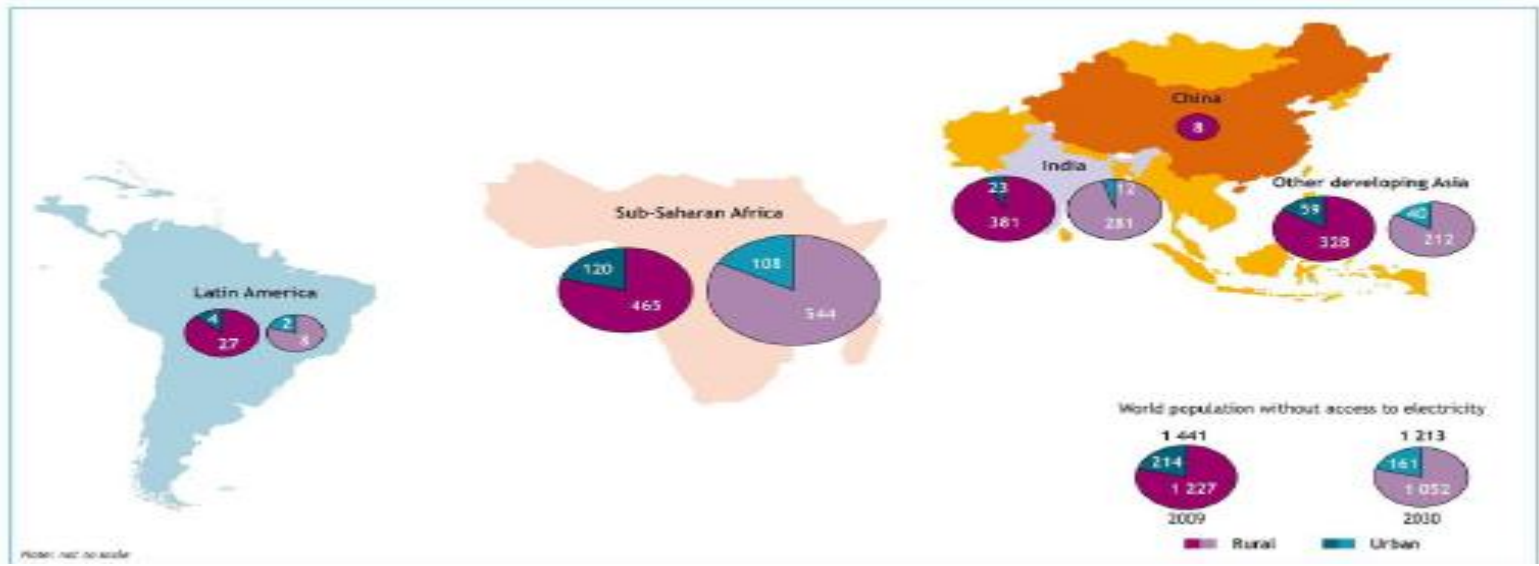

Source: International Energy Agency 2010,p.10

Figure 3: Number of people without access to electricity in rural and urban areas in the new policies scenario (Million)

${ }^{3}$ The 2010 edition of the World Energy Outlook sets out three scenarios to 2035.The Current Policies Scenario takes into consideration only those policies and measures that had been formally adopted by mid-2010; the new Policies Scenario takes account of broad policy commitment that have already been announced; while the 450 Scenario assumes a pathway to 2035 with the objective of limiting the long term concentration of greenhouse gases in the atmosphere to 450 parts per million of $\mathrm{CO}_{2}$-equivalent.

Moreover, energy consumption in Organization for Economic and Development (OECD) countries is forecast to grow by $14 \%$, while, non-OECD countries will grow by $84 \%$. Also, over the next 25 to 30 years, nearly all the growth in energy demand, fossil fuel use, associated local pollution, and greenhouse emissions is forecast to come from the developing world. More broadly, the relationship between economic growth and energy consumption in the developing world has been, and is likely to continue to be, heavily influenced by the extent to which that growth is "pro-poor" - that is , by the extent to which growth improves the economic condition of those previously living in poverty. Further, the current forecasts for energy demand in developing world may be understated, because they do not accurately capture increased demand along the extensive margin.

Fig. 4 plots total energy use in the developed and developing worlds, using actual numbers from 1980 to 2008 and Energy Information Administration's (EIA) projections to 2035. Total energy includes consumption from the residential, industrial, commercial and transportation sectors from different primary sources, including petroleum, natural gas, coal, electricity generated from fossil fuels, as well as from nuclear, hydro, geothermal, solar, wind and biomass. The solid lines, plotting the actual numbers demonstrates accelerating growth in developed world energy consumption in the most recent ten to fifteen years. The squares and triangles plot the EIA's forecasts for how energy use will evolve. Clearly, much of the growth is expected to be in the developing world. By 2035, developing world demand will almost double developed world demand. Other organizations such as the International Energy Agency projects compound annual growth in non-OECD countries energy demand of 2.0 percent through 2030, while, the U.S. Energy Information Administration projects compound annual growth of 2.2 percent through 2035 [8]. 


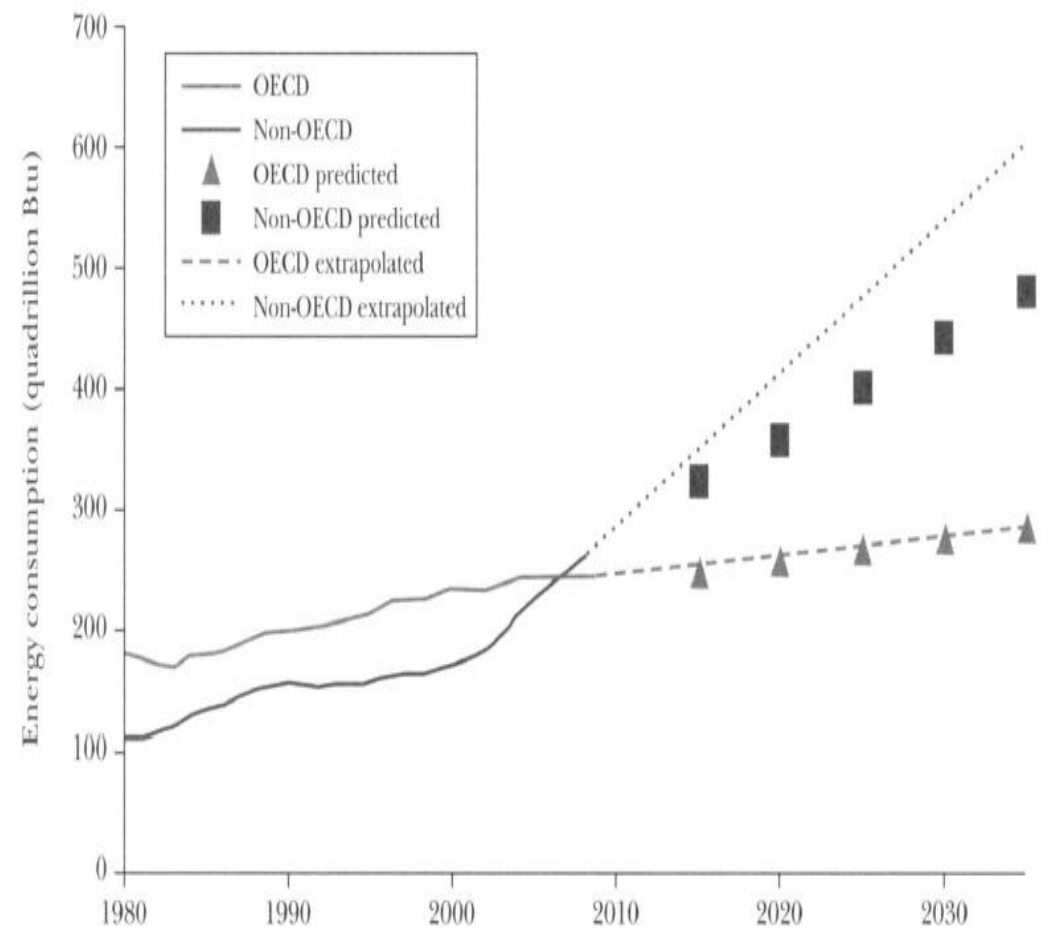

Source: Wolfram et. al. 2012,p.120

Figure 4: Energy consumption in the developing and developed worlds: actual and forecast

Poor energy constitutes a significant obstacle to social and economic development in developing countries. The links between energy and development are illustrated clearly in Africa, where, despite a wealth of resources, energy use per capita is less than one-third of the global average in 2035 [9]. Apparently, poor energy supply remains a challenge in the developing countries. These phenomena require urgent action such as the application of new technologies for the development of renewable energy sources and improved energy efficiency. It therefore becomes necessary to advance technology to fit into the existing condition. This calls for the need to invent and develop appropriate technologies in the context of the developing world, while, simultaneously improving the energy situation.

\section{Computers as interactive tools for learning}

$46.2 \%$ of the students attested to their departments having computers as an interactive tool for learning, $42 \%$ claimed their departments of study had no computers, while, $11.8 \%$ were not sure whether or not their departments had computers for students use. $96.2 \%$ see the need for computer as an interactive tool for learning, while, $1.9 \%$ claimed they had no need of the computer and another set of $1.9 \%$ were not sure whether or not they needed computer for learning (Fig. 5). 


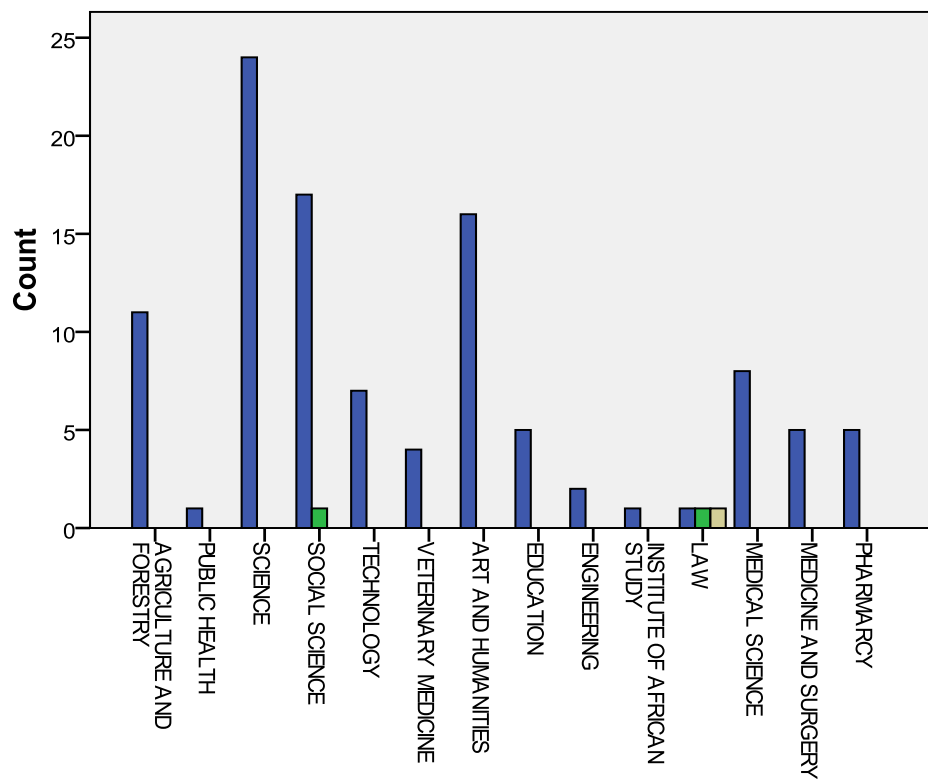

needcomputer

$\square \mathrm{YES}$

$\square$ NO

$\square$ NOT SURE

Source: Field Survey in Nigerian Higher Institutions of Learning, 2013

Figure 5: Frequency distribution of responses to the need of computer for learning for some departments

\subsection{Students' use of computer}

Fig. 6 shows the proportion that use computer regularly, not regularly and not at all. These three categories of users gave poor energy supply (Blue bar), do not have access to any and other reasons for not using the computer as much as they would have loved to.

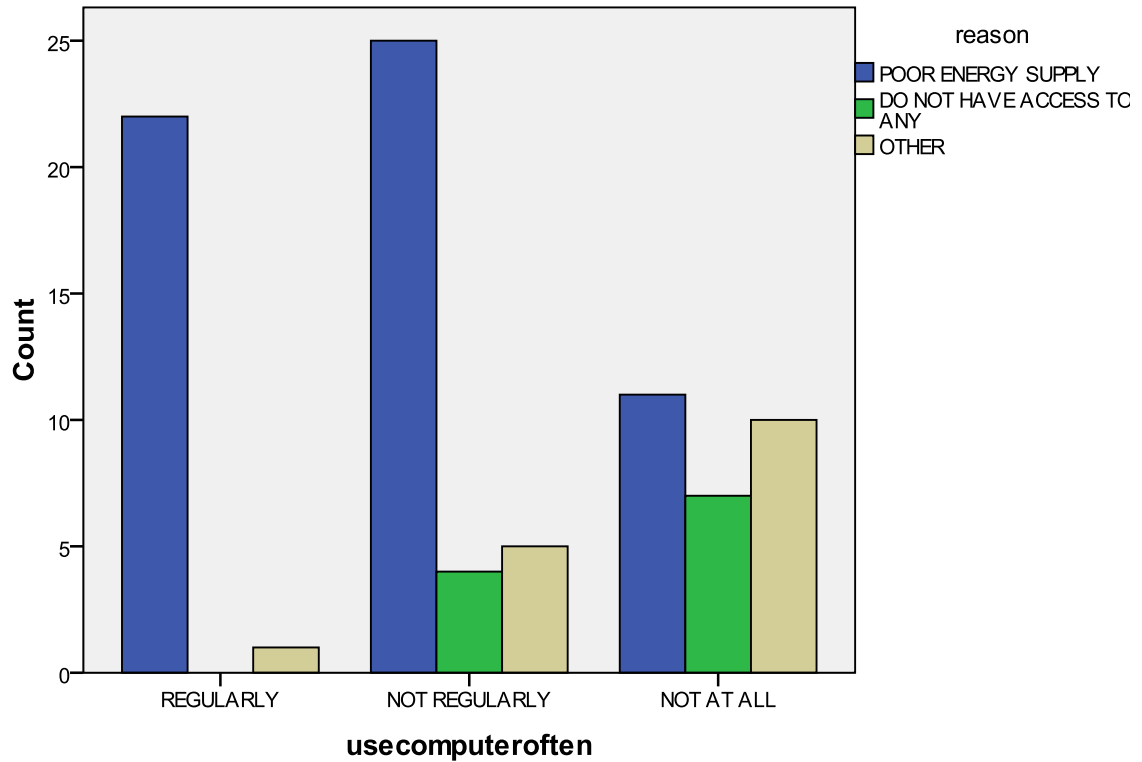

Source: Field Survey in Nigerian Higher Institutions of Learning, 2013

Figure 6: Frequency distribution of respondents reasons for not using computer regularly, not regularly and at all should last

Number of hours battery last when there is no energy supply/Number of hours users wish battery

For the proportion that had personal computers, an investigation into the number of hours their battery last after being fully charged when there is no energy supply revealed the results displayed in table $3.44 .1 \%$ had a battery life span below 2 hours,33.1\% had a battery life span between 2-4 hours, while $22.8 \%$ had a battery life span above 4 hours (Table 1).45.5\% wished their battery life span last above 8 hours,37.9\% wished it last between 4-8 hours, $15.2 \%$ wished it last between 2-4 hours, while, 1.4\% wished it last 2 hours (Table 2). 
Respondents with different categories of existing battery computer life, ranging from less than 2 hours to above 4 hours, have a large proportion of users who wish for a battery life lasting above 8 hours (Fig. 7).

Table 1: Number of Hours Computer Battery Last when there is No Energy Supply

\begin{tabular}{|ll|r|r|r|r|}
\hline Hours & & Frequency & Percent & Valid Percent & Cumulative Percent \\
\hline \multirow{4}{*}{ Valid } & Below 2hours & 64 & 30.0 & 44.1 & 44.1 \\
& Btw 2-4hours & 48 & 22.5 & 33.1 & 77.2 \\
& Above 4hours & 33 & 15.5 & 22.8 & 100.0 \\
Missing & Total & 145 & 68.1 & 100.0 & \\
Total & System & 68 & 31.9 & & \\
\hline
\end{tabular}

Source: Field Survey in Nigerian Higher Institutions of Learning, 2013

Table 2: Number of Hours Respondents Wish Battery should Last in the Presence of Unreliable Energy Supply

\begin{tabular}{|ll|r|r|r|r|}
\hline Hours & & \multicolumn{1}{|c|}{ Frequency } & \multicolumn{1}{|c|}{ Percent } & \multicolumn{1}{|c|}{ Valid Percent } & Cumulative Percent \\
& Below 2hours & 2 & .9 & 1.4 & 1.4 \\
& Btw 2-4hours & 22 & 10.3 & 15.2 & 16.6 \\
Valid & Btw 4-8hours & 55 & 25.8 & 37.9 & 54.5 \\
& Above 8hours & 66 & 31.0 & 45.5 & 100.0 \\
& Total & 145 & 68.1 & 100.0 & \\
Missing & System & 68 & 31.9 & & \\
Total & & 213 & 100.0 & & \\
\hline
\end{tabular}

Source: Field Survey in Nigerian Higher Institutions of Learning, 2013
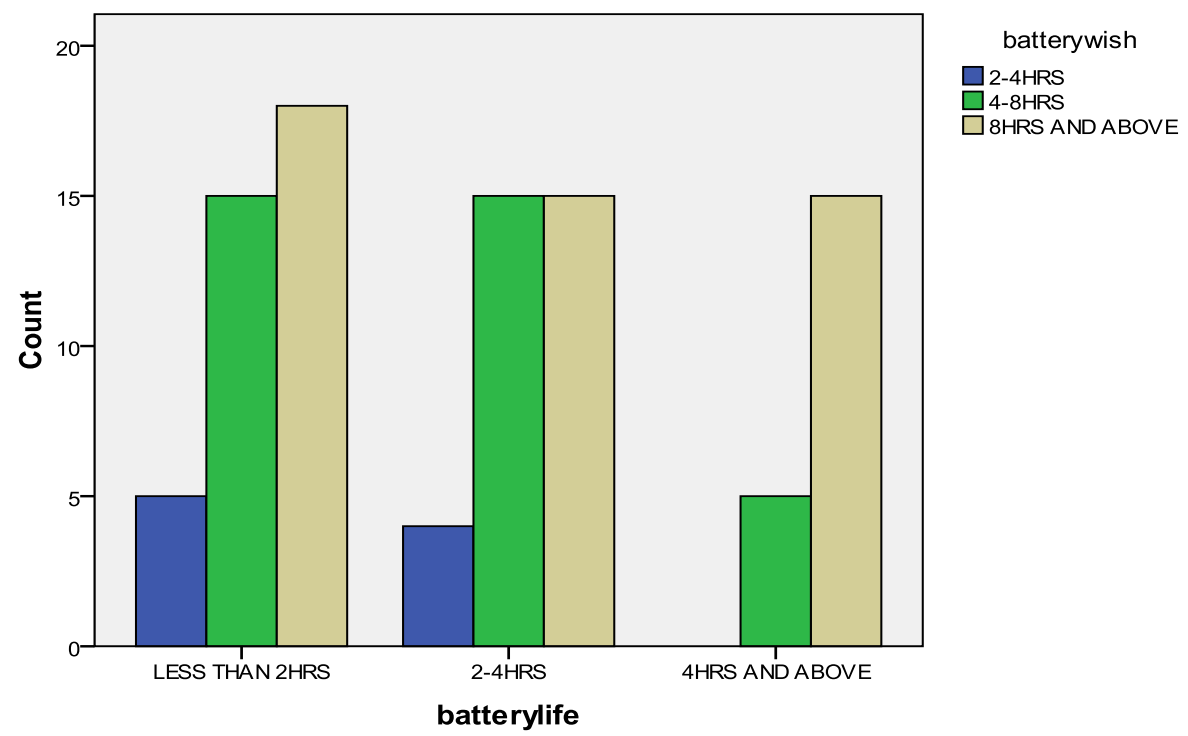

$\square$ 4-8HRS

$\square$ 8HRS AND ABOVE

Source: Field Survey in Nigerian Higher Institutions of Learning, 2013

Figure 7: Frequency distribution of number of hours that respondents wish the battery life of computer should last in the presence of unreliable energy supply

\section{Technologies to make the computer more relevant}

Further investigation on technologies that can make the computer more relevant to users and adaptable to the environment revealed $51.4 \%$ suggesting longer battery life, $21.8 \%$ suggesting double battery pack, $8.5 \%$ suggesting both longer battery life and double battery pack and 7\% suggesting a reduction in the energy consumption of component parts of the computer (Table 3). Fig. 8 shows a selection of responses on enhancing suitability of computer to the environment and increase usage for learning activities. The highest priority is on longer battery life, followed by producing the computer with two battery packs rather than the single regular battery pack presently being manufactured and a suggestion on reducing the energy consumption of the component parts of the computer system. 
Table 3 : Accessories that can make Computer more Useful and Adaptable to your Environment

\begin{tabular}{|c|c|c|c|c|c|}
\hline \multicolumn{2}{|c|}{ Accessories } & Frequency & Percent & Valid Percent & Cumulative Percent \\
\hline \multirow{10}{*}{ Valid } & Long Battery life & 73 & 34.3 & 51.4 & 51.4 \\
\hline & Double battery pack & 31 & 14.6 & 21.8 & 73.2 \\
\hline & $\begin{array}{l}\text { Reduced energy consumption of } \\
\text { components parts }\end{array}$ & 10 & 4.7 & 7.0 & 80.3 \\
\hline & $\begin{array}{l}\text { Long Battery life, Double battery } \\
\text { pack }\end{array}$ & 12 & 5.6 & 8.5 & 88.7 \\
\hline & $\begin{array}{l}\text { Double battery \& Reduced energy } \\
\text { consumption by component part }\end{array}$ & 1 & .5 & .7 & 89.4 \\
\hline & $\begin{array}{l}\text { Long Battery life, Double battery \& } \\
\text { Reduced energy consumption by } \\
\text { component part }\end{array}$ & 8 & 3.8 & 5.6 & 95.1 \\
\hline & $\begin{array}{l}\text { Longer battery life \& Reduced } \\
\text { energy consumption by component } \\
\text { part }\end{array}$ & 3 & 1.4 & 2.1 & 97.2 \\
\hline & Durable computer hardware & 2 & .9 & 1.4 & 98.6 \\
\hline & Consistent Power supply & 2 & .9 & 1.4 & 100.0 \\
\hline & Total & 142 & 66.7 & 100.0 & \\
\hline Missing & System & 71 & 33.3 & & \\
\hline Total & & 213 & 100.0 & & \\
\hline
\end{tabular}

Source: Field Survey in Nigerian Higher Institutions of Learning, 2013

Table 5 gives the results of further investigations relating to accessories that should be added to the computer to enhance learning skills in the environment. Ready and fast internet access accessories, educative computer softwarellearning kits, longer battery life, printer, consistent power supplylsolar energy, faster processor, larger ram and hard drive space, free access to online journals and libraries were top priorities. Fig. 8, showed the proportion of students that acknowledge the need for computer in learning, those that think they do not need the computer to learn and those that are not sure. A higher proportion of these categories of students suggest longer battery life, followed by producing the computer with two battery packs rather than the single regular battery pack presently being manufactured and a suggestion on reducing the energy consumption of the component parts of the computer system. Whereas, Fig. 9, shows the distribution of students that have personal computers and their opinion on accessories that shoud be added to the computer sytem to enhance learning skills. Findings were the same as the later as regards battery life and the proportion that desire more application was on the high side.

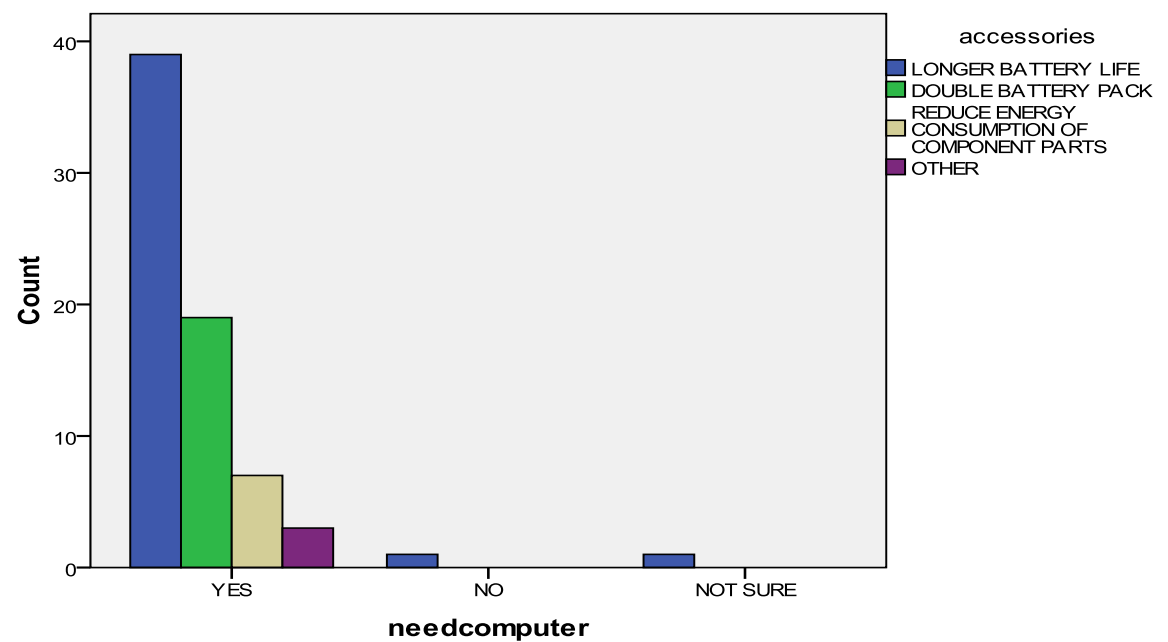

Source: Field Survey in Nigerian Higher Institutions of Learning, 2013

Figure 8: Frequency distribution of responses to the need of computer for learning and respondents suggestions of accessories to promote usage of the computer and make it more suitable for the environment 


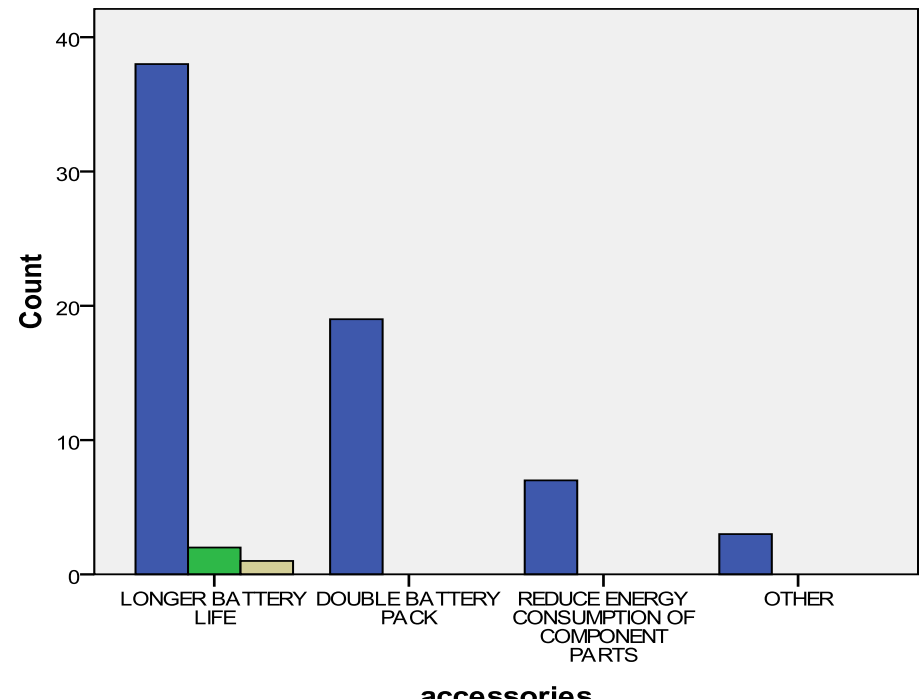

needcomputer

$\square$ YES

$\square$ NOT SURE

accessories

Source: Field Survey in Nigerian Higher Institutions of Learning, 2013

Figure 9: Frequency distribution of respondents to the need of computer for learning and respondents suggestions of accessories that can be added to the computer to promote learning activities in the environment

Table 5: Accessories that can be added to Computer to Enhance Learning/Productive Skills

\begin{tabular}{|c|c|c|c|c|}
\hline Accessories & Frequency & Percent & Valid Percent & Cumulative Percent \\
\hline $\begin{array}{l}\text { Ready \& fast internet access } \\
\text { accessories }\end{array}$ & 9 & 4.2 & 12.2 & 12.2 \\
\hline Longer Battery life & 34 & 16.0 & 45.9 & 58.1 \\
\hline Printer, Fax machine, Scanner & 1 & .5 & 1.4 & 59.5 \\
\hline Light pen, Fax machine, Scanner & 1 & .5 & 1.4 & 60.8 \\
\hline Keyboard Light & 1 & .5 & 1.4 & 62.2 \\
\hline Printer & 2 & .9 & 2.7 & 64.9 \\
\hline Headset \& USB cables & 1 & .5 & 1.4 & 66.2 \\
\hline Durable computer hardware & 1 & .5 & 1.4 & 67.6 \\
\hline $\begin{array}{l}\text { Faster Processor, Larger ram \& } \\
\text { hard drive space }\end{array}$ & 2 & .9 & 2.7 & 70.3 \\
\hline $\begin{array}{l}\text { Free access to online journals and } \\
\text { libraries }\end{array}$ & 2 & .9 & 2.7 & 73.0 \\
\hline $\begin{array}{l}\text { Tutorial/Training on use of } \\
\text { computer accessories }\end{array}$ & 1 & .5 & 1.4 & 74.3 \\
\hline $\begin{array}{l}\text { Reduction of heat emission of the } \\
\text { computer, }\end{array}$ & 1 & .5 & 1.4 & 75.7 \\
\hline $\begin{array}{l}\text { An interactive voice chatting } \\
\text { software or programs }\end{array}$ & 1 & .5 & 1.4 & 77.0 \\
\hline External drive & 1 & .5 & 1.4 & 78.4 \\
\hline Extra battery & 1 & .5 & 1.4 & 79.7 \\
\hline $\begin{array}{l}\text { Availability of mass } \\
\text { media(T.V.,Radio), Online books } \\
\text { readily available }\end{array}$ & 1 & .5 & 1.4 & 81.1 \\
\hline $\begin{array}{l}\text { Consistent power supplyl } \\
\text { Solar panel }\end{array}$ & 2 & .9 & 2.7 & 83.8 \\
\hline $\begin{array}{l}\text { A device to convert voice lectures } \\
\text { to readable lectures note for } \\
\text { futures use }\end{array}$ & 1 & .5 & 1.4 & 85.1 \\
\hline $\begin{array}{l}\text { Educative Computer } \\
\text { softwarelLearning kits }\end{array}$ & 10 & 4.7 & 13.5 & 98.6 \\
\hline $\begin{array}{l}\text { Scanners, Flash drive, Printers \& } \\
\text { External hard disk }\end{array}$ & 1 & .5 & 1.4 & 100.0 \\
\hline
\end{tabular}

Source: Field Survey in Nigerian Higher Institutions of Learning, 2013 


\section{Tests of Significance}

The Chi - Square statistic compares the tallies or counts of categorical responses between two (or more) independent groups. Calculate the Chi Square statistic $\chi^{2}$ by completing the following steps:

Step 1: For each observed value denoted $O$ in the table, subtract the corresponding expected value denoted $E$, that is, $(\mathrm{O}-\mathrm{E})$

Step 2: Square the difference: $\left[(\mathrm{O}-\mathrm{E})^{2}\right]$

Step 3: Divide the squares obtained for each cell in the table by the expected number for that cell $\left[(\mathrm{O}-\mathrm{E})^{2} / \mathrm{E}\right]$

Step 4: Sum all the values for $(\mathrm{O}-\mathrm{E})^{2} / \mathrm{E}$ Therefore, the test statistic is given $\chi^{2}=\sum \frac{(\text { observedvalue }-\exp \text { ectedvalue })^{2}}{\exp \text { ectedvalue }}$

The chi-square significance test measures the likelihood that the observed association between the independent variable and the dependent variable is caused by chance. In practical terms, a chi - square with low P-value indicates statistical significance, in which case the null hypothesis is rejected. SPSS was used for statistical analysis.

Educational development/ Information and communication technology

At $5 \%$ level of significance, the p- value was 0.001 ; therefore, the null hypothesis was rejected. The conclusion revealed a strong association between educational development and information and communication technology.

Poor energy supply/ Computer as teaching aid

At 5\% level of significance, the p- value was 0.001 , therefore, the null hypothesis was rejected; analysis showed there is a significant impact of poor energy supply on the use of computer as teaching aid in developing countries.

Poor energy supply/ Information and communication technology

At $5 \%$ level of significance, the p- value was 0.085 ; therefore, the null hypothesis was not rejected. It was concluded that there is no significant impact of poor energy supply to information and communication technology in developing countries. This suggests the existence of other inhibiting factors in the environment.

Technological innovation/ Hours the computer can be put to use

At $5 \%$ level of significance, the p- value was 0.001 ; therefore, the null hypothesis was rejected. The conclusion is that technological innovation has a significant effect on the number of hours the computer can be put to use.

\section{Computer usage/Energy supply}

At 5\% level of significance, the $\mathrm{p}$ - value was 0.001 ; therefore, the null hypothesis was rejected. The conclusion revealed a strong dependency between computer use and energy supply.

\section{Conclusion}

This study provides empirical evidence to support existing literature [1],[2],[3] on the possibilty of adapting technology to suit local needs, improve energy efficiency and to acheive economic goals without necessarily improving energy supply. Apparently, there is need to maximize the full potentials of the computer through technological innovation to enhance educational development and to expose students across the globe to equal platforms and opportunities for learning. One clear evidence is the need to adapt computer manufacturing technology to suit the existing unreliable energy situation in developing countries, so that students will no longer be limited by unreliable energy supply.

The computer is an indispensable interactive tool for learning that can enhance educational development and in the long run aid economic growth. Findings suggests that computers with longer battery life, or two battery packs rather than the single regular battery pack presently being manufactured and/or possibly a reduction in the energy consumption of the component parts of the computer system will likely increase hours of use for students in the face of unreliable energy supply. Other features that may be added to the computer to enhance educational development in developing countries is the inclusion of educative computer softwarellearning kits, textbooks, faster processor, larger ram and hard drive space and free access to 
online journals and libraries. To be sure we are better informed and well guided, further investigations on suitablility and increasing the efficiency of computers for learning in other parts of the developing world is highly recommended.

\section{Acknowledgement}

We acknowledge the UNESCO Chair in Technologies for Development for its financial support which enabled the results of this research to be presented at the UNESCO Chair International Conference on Technologies for Development (Tech4Dev 2014). We are also grateful to partcipants at the conference whose contributions have helped to improve the quality of our presentation.

\section{References}

[1] C. Weiss, Mobilizing technology for developing countries, Science New Series, 203(4385), 1979, $1083-1089$.

[2] J. James, Sharing mechanisms for information technology in developing countries, social capital and quality of life, Social Indicators Research, 94(1), 2009, 43-59.

[3] J. Ashworth, Technology diffusion through foreign assistance: Making renewable energy sources available to the world's poor, Policy Sciences, 11(3), 1980, 241-261.

[4] J. Goldemberg., T.B. Johansson , A.K.N. Reddy and R.H. Williams, Basic needs and much more with one kilowatt per capita, Ambio, 14(4/5), 1985,190 - 200.

[5] United Nations Development Programme, World energy assessment: Energy and the challenge of sustainable development, Jose Goldemberg (ed.), New York, 2000.

[6] The Academy of Sciences for the Developing World (TWAS), Sustainable energy for developing countries: A report to the academy of sciences for the developing world, Dilip Ahuja and Marika Tatsutani (ed.), Italy, 2008.

[7] IEA, International Energy Agency, Special early excerpts of the world energy outlook 2010 for the UN General Assembly on the Millennium Development Goals. OECD/IEA, Paris, 2010.

[8] Catherine Wolfram, Orie Shelef and Paul Gertler, How will energy demand develop in the developing world? The Journal of Economic Perspectives, 26(1), 2012, 119-138

[9] IEA, International Energy Agency, Executive Summary World Energy Outlook 2013, OECD/IEA, Paris, 2013. 